\title{
Drug quality deviations: notifications in a sentinel hospital in Ceará
}

\author{
Elana Figueiredo CHAVES $^{1}$ (D) , Juliana Alves GUIMARÃES ${ }^{1}$ (D) , Antonia Mesquita MORORÓ1, Bruna Cardoso MARTINS ${ }^{2}$ (D), \\ Andreína Fontenele TEIXEIRA ${ }^{1}$ (D)
}

${ }^{1}$ Serviço de Farmácia, Hospital Universitário Walter Cantídio, Fortaleza, Ceará, Brasil; ${ }^{2}$ Faculdade de Farmácia, Universidade Federal do Ceará

Corresponding author: Chaves EF, elanafigueiredo@gmail.com

Submitted: 02-05-2020 Resubmitted: 19-07-2020 Accepted: 29-07-2020

Peer review: blind reviewers

\begin{abstract}
Objective: To characterize the drug quality deviation (DQM) notification and their financial impact of a sentinel network university hospital in Ceará. Methods: This is a cross-sectional observational pharmacovigilance study carried out in Fortaleza-CE, through spontaneous reports of DQM from January 2016 to June 2017. Data was obtained from the patient's records, registered and analyzed using Excel spreadsheets. Results: A total of $49(84.48 \%)$ reports were included in this study, with a monthly average of 2.72 notifications. These came mainly from the pharmacy $(n=14 ; 28.57 \%)$ and medical clinics ( $n=12 ; 24.49 \%)$, with nurses ( $n=28 ; 57.14 \%)$ and pharmacists ( $n=13$; $26.53 \%)$ being the largest notifiers. A total of 92 drugs were used, being blood substitutes and perfusion solutions ( $n=50 ; 54.35 \%)$, antibacterials for systemic use $(n=12 ; 13.04 \%)$ and immunoglobulins $(n=6 ; 6.52 \%)$ the most frequent. Injectable pharmaceutical formulations were more frequent $(91,30 \% ; n=84)$. The most frequently observed DQM were the presence of foreign body / material in suspension ( $n=16 ; 32.65 \%)$ and crack / bubble / leak $(n=14 ; 28.57 \%)$. The supplier was contacted in em $65,31 \%(n=32)$, of the cases, with formal responses received in $65,62 \%(n=21)$ of them. The manufacturer took responsibility for DQM in $38,10 \%(n=8)$ of cases. The notification to the National Health Surveillance Agency (ANVISA) occurred in 20,41\% of the cases. The reimbursement of the value of the drug by the producer laboratories contacted occurred in $25 \%(n=8)$ of the cases, corresponding to a value of $R \$ 4,254.97$. Conclusions: The importance of conducting DQM notifications is evident since these can ensure better knowledge about health products on the market and safer products for patients and health professionals.
\end{abstract}

Keywords: pharmacovigilance, delivery of health care, public health surveillance.

\section{Desvios de qualidade de medicamentos: notificações em um hospital sentinela do Ceará}

\section{Resumo}

Objetivo: Caracterizar as notificações de desvio de qualidade de medicamentos (DQM) e seu impacto financeiro um hospital universitário da rede sentinela do Ceará. Métodos: Trata-se de um estudo observacional transversal de farmacovigilância realizado em FortalezaCE, através de notificações espontâneas de DQM no período de janeiro/2016 a junho/2017. Os dados foram coletados em formulário próprio a partir de prontuários dos pacientes e, em seguida, compilados e analisados em planilhas de Excel. Resultados: Foram incluídas 49 notificações neste estudo, com média mensal de 2.72 notificações. Estas foram provenientes principalmente dos setores de farmácia $(n=14 ; 28,57 \%)$ e de clínicas médicas $(n=12 ; 24,49 \%)$, sendo os profissionais enfermeiro $(n=28 ; 57,14 \%)$ e o farmacêutico ( $n=13$; 26,53\%) os principais notificadores. Foram envolvidas 92 unidades de medicamentos, sendo os substitutos sanguíneos e soluções de perfusão ( $n=50 ; 54,35 \%)$, antibacterianos para uso sistêmico ( $n=12 ; 13,04 \%)$ e as imunoglobulinas $(n=6 ; 6,52 \%)$ os mais frequentes. Quanto à forma farmacêutica, 91,30\% ( $n=84)$ eram medicamentos injetáveis. Os DQM mais frequentemente observados foram a presença de corpo estranho/material em suspensão ( $n=16 ; 32,65 \%)$ e rachadura/bolha/vazamento $(n=14 ; 28,57 \%)$. 0 contato com o fornecedor ocorreu em $65,31 \%(n=32)$, com resposta formal em $65,62 \%(n=21)$ das notificações. A indústria assumiu a responsabilidade pelo $\mathrm{DQM}$ em $38,10 \%(\mathrm{n}=8)$ dos casos com resposta. A notificação à Agência Nacional de Vigilância Sanitária (ANVISA) ocorreu em $20,41 \%$ dos casos. O ressarcimento do valor do medicamento pelos laboratórios produtores contactados ocorreu em $25 \%$ ( $n=8$ ) dos casos, correspondendo a um valor de $\mathrm{R} \$$ 4.254,97. Conclusão: A importância da realização de notificações de DQM é evidente uma vez que estas podem garantir melhor conhecimento sobre os produtos de saúde no mercado e maior segurança para os pacientes e profissionais de saúde.

Palavras-chave: farmacovigilância, assistência à saúde, vigilância sanitária. 


\section{Introduction}

The risk of drug-related accidents is an important problem in the hospital setting, which can compromise both the quality of care provided to the patient and the safety of the health professional. ${ }^{1}$ In this context, the quality control of drugs already available on the market, through pharmacovigilance actions, is of fundamental importance for the quality performance of hospital practices, for patient safety, and for the purpose of adopting relevant intervention measures by the health authorities. ${ }^{2,3}$

In Brazil and in the world, following the release of the To Err is Human report of the Institute of Medicine (IOM) in 1999, the subject of patient safety and adverse events gained relevance and provided a mobilization of health authorities to prevent avoidable errors and to monitor and quantify their occurrences. ${ }^{4}$ In order to improve post-marketing surveillance of medications in Brazil, the National Health Surveillance Agency (Agência Nacional de Vigilância Sanitária, ANVISA) created the Sentinel Network in 2002. Currently, it consists of 225 hospitals, with 12 located in Ceará. ${ }^{5}$ Furthermore, through Ordinance MS/GM/2013, the Ministry of Health instituted the National Patient Safety Program (Programa Nacional de Segurança do Paciente, PNSP), with the aim of contributing to the qualification of health care in Brazilian health institutions. ${ }^{4}$ Despite these initiatives, studies on drug quality deviations and on the economic impact they generate on hospital institutions are still scarce.

Unicentric national studies signal a prevalence of spontaneous reports of drug quality deviations in hospitals that is variable depending on the methodology of the study, and can be between $15.2 \%$ and $60.3 \%$ of the notifications in pharmacovigilance. ${ }^{6,7}$

Drug quality deviations are understood as the departure from the quality parameters established for a product or process, which may or may not cause harms to individual and collective health. ${ }^{8}$ Deviations can be related to organoleptic, physical-chemical or general changes (problems with the label, cracks and bubbles in the packaging material). ${ }^{9,10}$ The occurrence of these problems can compromise patient safety, prolonging hospitalization, causing permanent or temporary injuries, and putting the patient's life at risk. In view of the suspicion of a quality deviation, it is up to the competent health professional to make a technical complaint notification. ${ }^{2,11}$

The performance of quality deviation notifications allows for the knowledge of cases by hospital managers, contributing to the process of selection and acquisition of quality products and, possibly, avoiding the re-entry of products of dubious quality. ${ }^{12}$ In addition, these notifications subsidize the ANVISA for the adoption of appropriate sanitary measures. ${ }^{3}$ This study was developed with the objectives of characterizing the profile of drug quality deviation notifications and of assessing their financial impact in a university hospital in the State of Ceará belonging to the Sentinel Network.

\section{Methods}

This is a cross-sectional observational pharmacovigilance study carried out in a university hospital of Fortaleza, Ceará, through spontaneous drug quality deviation notifications recorded from January/2016 to June/2017. The research was carried out with the authorization of the head of service of the hospital's risk management area and was part of a study by the clinical pharmacy service in pharmacovigilance of the institution. It was carried out in accordance with the guidelines and regulatory standards for research involving human beings, being submitted to the Research Ethics Committee of the Walter Cantídio University Hospital and approved under opinion No. 2,699,465 and CAAE No. 74283417.4.0000.5045.

The study locus is an important reference center for health care in the State of Ceará linked to the Unified Health System (Sistema Único de Saúde, SUS), as well as an important venue for the training of human resources and research development. This institution provides highly complex outpatient and hospital care, has 262 beds, and is part of the Brazilian Network of Sentinel Hospitals of the ANVISA since 2011, with an active pharmacovigilance service since 1995. The hospital under study has a combined drug distribution system, being distributed individually after the 24-hour medical prescription is released, and collectively for the large volume solutions and drugs in the form of solution, suspension or syrups.

The quality deviations were reported through VIGIHOSP, a software program with access available to all the health professionals at the institution. VIGIHOSP - Health Surveillance and Risk Management - is a tool that aims to streamline the identification and solution of problems occurred in the institution, facilitating the decisionmaking process in actions to improve the quality of the services provided to the patients. Through this system, incidents can be notified at any time and anonymously so that proper assessment and decision-making can be carried out. During the registration of the quality deviation in VIGIHOSP, the notifying professional provides information about the observed problem, classifying it in the categories previously established by the software: 1) Regarding the type of quality deviation observed, which can be a) absence of label/content, b) altered color, c) foreign body/material in suspension, d) difficulty in homogenization/solubilization, e) altered smell, f) precipitation, g) labeling problems: illegible, inadequate; does not have important information, h) label problem: illegible, inadequate, i) less quantity than stated on the packaging, j) crack/bubble/leak, I) turbidity, m) other; and 2) Regarding the quality deviation location, which can be a) packaging, b) label, c) suspension/solution, d) tablet/capsule/pill, e) powder, f) package insert, g) other.

After notification of the deviation by the health professional in the system, risk management assesses the process and seeks additional information for better understanding of the case and decision-making. The actions taken involve resolving the case by contacting the supplier, sending a response letter to the notifying health professional and reporting to the ANVISA.

For this study, notifications with analysis completed by risk management were included. Unresolved notifications were excluded due to the lack of data necessary to investigate the causes of the quality deviation, such as the name of the manufacturer's laboratory and the expiration date.

The analysis of the notifications involved the following variables: month/year of occurrence, care unit, notifying professional, ATC (Anatomical Therapeutic Chemical) classification level two, number of items, location of the deviation, nature of the deviation, notification to the supplier/industry and to the ANVISA, and measures taken after the notification. To estimate the budgetary impact, the deterministic method was used, a type of mathematical model in which the same budgetary inputs or initial 
conditions will invariably produce the same products or results in the end, following the guidelines suggested by the Ministry of Health. ${ }^{12,13}$ Cost data were obtained from the institution's internal inventory management program at the Pharmaceutical Supply Center.

With regard to data analysis, the categorical variables of the study were expressed in absolute and relative frequencies and the numerical variables, in the form of arithmetic mean and standard deviation using Microsoft Office Excel ${ }^{\circledR} 2013$.

\section{Results}

During the 18 months of the study, a total of 58 voluntary drug quality deviation notifications were received in VIGIHOSP. Of these, 49 were included in the study because they had all the information necessary to complete the investigation.

The monthly mean number of notifications included in the study was 2.72 ( $S D \pm 1.9$ ). The notifications came from different sectors of the hospital, with Pharmacy and Medical Clinics standing out. Regarding the type of notifying professional, the analysis showed that those who performed the most notifications were the nurse and the pharmacist (Table 1). The notifications involved a total of 92 units of 30 different drugs, with a mean of 1.88 drugs/ notification $(S D \pm 5.57)$ and a median equal to one.

Table 1. Types of assistance unit and of professional notifying drug quality deviations in a university hospital of Fortaleza-CE(jan/2016 to jun/2017).

\begin{tabular}{lcc}
\hline Assistance Unit & N & \% \\
\hline Pharmacy & 14 & 28.57 \\
Medical Clinics & 12 & 24.49 \\
Surgical Clinics & 8 & 16.33 \\
Surgical Center & 6 & 12.24 \\
Intensive Care Unit & 6 & 12.24 \\
Chemotherapy & 2 & 4.08 \\
Bone marrow transplantation & 1 & 2.04 \\
Notifying professional & $\mathrm{N}$ & $\%$ \\
Nurse & 28 & 57.14 \\
Pharmacist & 13 & 26.53 \\
Pharmacy intern & 2 & 4.08 \\
Nursing technician & 2 & 4.08 \\
Assistant physician & 1 & 2.04 \\
Laboratory technician & 1 & 2.04 \\
Not reported & 2 & 4.08 \\
Total & $\mathbf{4 9}$ & $\mathbf{1 0 0 . 0 0}$ \\
\hline
\end{tabular}

All the items involved were within the validity period at the time of notification, and screening by risk management was possible through product batch information. The most frequent medications were mannitol ( $n=40 ; 43.47 \%)$, human immunoglobulin $(n=6$; $6.52 \%)$, and ringer lactate serum $(n=5 ; 5.43 \%)$. When analyzed by the ATC classification, it was observed that blood substitutes and perfusion solutions ( $n=50 ; 54.35 \%)$, antibacterials for systemic use $(n=12 ; 13.04 \%)$, and immunoglobulins ( $n=6 ; 6.52 \%)$ were the most frequently involved in the notifications (Table 2 ).
Table 2. ATC classification level 2 of the drugs involved in drug quality deviation notifications in a university hospital of FortalezaCE (Jan/2016 to Jun/2017).

\begin{tabular}{lcc}
\hline ATCa classification of the medications & N & \% \\
\hline Blood substitutes and infusion solutions & 50 & 54.35 \\
Antibacterial drugs for systemic use & 12 & 13.04 \\
Immunoglobulins & 6 & 6.52 \\
Anesthetics & 3 & 3.26 \\
Antiviral drugs for systemic use & 3 & 3.26 \\
Medications for gastrointestinal functional disorders & 3 & 3.26 \\
Medications for obstructive diseases of the airways & 3 & 3.26 \\
Anti-diarrheal agents and gastrointestinal anti- & 2 & 2.17 \\
inflammatory/anti-infectious agents & 2 & 2.17 \\
Cardiac therapy & 2 & 2.17 \\
Cardiac drugs & 6 & 6.52 \\
Others* & $\mathbf{9 2}$ & $\mathbf{1 0 0 . 0 0}$ \\
Total & & \\
\hline
\end{tabular}

aTC: Anatomical Therapeutic Chemical

*ATC classes with a frequency below 2 were classified as Others.

The most frequent pharmaceutical formulations in cases of quality deviations were injectable solutions/suspensions $(n=84 ; 91.3 \%)$, followed by oral formulations ( $n=8 ; 8.7 \%)$. As for the place where the quality deviation was observed, the notifications indicated a higher frequency in suspension/solution ( $n=25 ; 51.02 \%)$, followed by packaging ( $n=14 ; 28.57 \%)$. The most frequently observed quality deviations were the presence of a foreign body/suspended material $(n=16 ; 32.65 \%)$ and crack/bubble/leak $(n=14 ; 28.57 \%)$ in the medications (Table 3 ).

Table 3. Characterization of drug quality deviations in terms of location and type in a university hospital of Fortaleza-CE (Jan/2016 to Jun/2017).

\begin{tabular}{lcc}
\hline Place where the quality deviation was observed & N & \% \\
\hline Suspension/Solution & 25 & 51.02 \\
Packaging & 14 & 28.57 \\
Label & 3 & 6.12 \\
Tablet/Capsule/Pill & 1 & 2.04 \\
Powder & 1 & 2.04 \\
Others & 5 & 10.20 \\
Type of quality deviation observeda & $\mathbf{N}$ & $\%$ \\
Foreign body/material in suspension & 16 & 32.65 \\
Crack/Bubble/Leak & 14 & 28.57 \\
Absence of label/content & 4 & 8.16 \\
Quantity below the one reported in the packaging & 4 & 8.16 \\
Altered color & 3 & 6.12 \\
Lack/Reduction of the therapeutic effect & 3 & 6.12 \\
Altered color + Presence of foreign body & 2 & 4.08 \\
Problem in the label: illegible, inadequate & 2 & 4.08 \\
Others & 1 & 2.04 \\
Total & 49 & 100.00 \\
\hline
\end{tabular}

aClassification based on the VIGIHOSP system.

The notifications were accompanied by the sending of the drug sample by the notifier in 38 cases (77.55\%). Contact with the laboratory occurred in 32 of the notifications (65.31\%) and the drug sample with suspected quality deviation was sent to the laboratory in 27 cases (55.10\%). Of these, there was a formal 
response from the manufacturer in 21 situations (65.62\%). Of these situations in which there was a response, in 8 cases (38.10\%) the manufacturers assumed responsibility for the quality deviation in question, stating that the problems were punctual and that in the retention samples no deviation was identified $(n=5)$, what measures are being taken to solve the problem $(n=2)$, and that the reported situation did not represent a quality deviation but an organoleptic characteristic of the medication $(n=1)$. The manufacturers were totally indifferent to the notification in three cases, not sending an e-mail response and not reimbursing the amount (Figure 01). The quality deviations whose responsibility was not assumed by the company $(n=13)$ were justified by the suppliers as consequences of 1 ) failure to send the sample with a quality deviation and retention sample without non-conformities, 2) failure to follow the instructions for use by the professionals and 3) packaging damage due to improper storage, transportation or handling.

The analysis of the financial impact showed that, among the cases in which contact was made with the drug manufacturer's laboratory, reimbursement occurred in $25 \%$ (8/32) of the cases, corresponding to a value of $R \$ 4,254.97$. The technical responsibility for the quality deviation was not formally carried out in writing by any of the 8 suppliers that made reimbursements.

Regarding the cases in which there was no reimbursement, the financial loss for the institution was at least $R \$ 804.88$, considering only direct costs. This amount corresponds to $0.0038 \%$ of the total amount spent on medications (approximately $\mathrm{R} \$ 21$ million) in the same period by the institution. The conclusion of the assessment by the risk management area occurred with a subsequent response to the notifying professional and to ANVISA in $83.67 \%(n=41)$ and $20.41 \%(n=10)$ of the cases, respectively.
Figure 1. Situational flow diagram of the quality deviation notifications in the study medications.

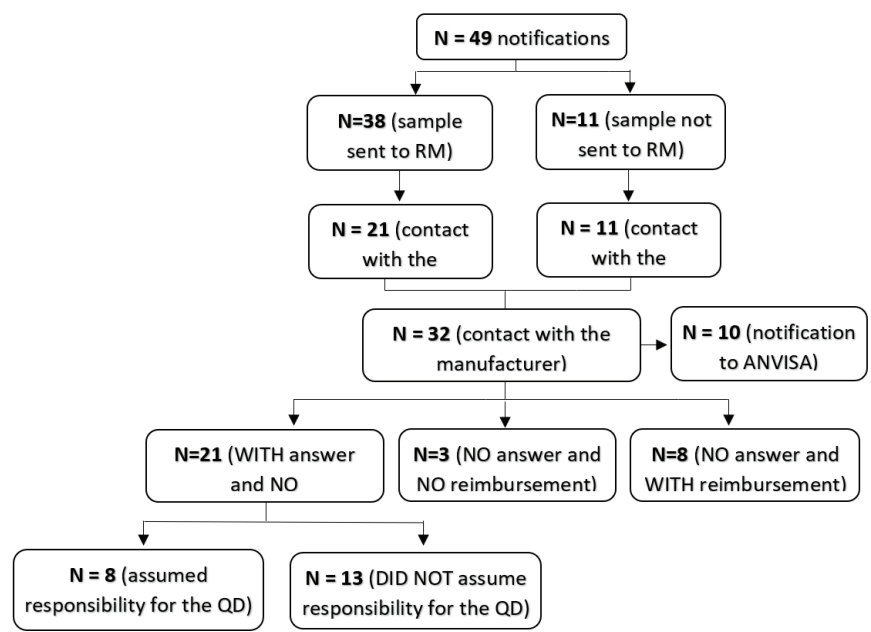

RM: Risk Management; QD: Quality Deviation

Table 4 describes five representative cases of the notifications that occurred in the study, detailing the drugs involved, the problems identified, and the pharmacovigilance actions performed.

Table 4. Examples of drug quality deviation notifications and pharmacovigilance actions carried out in the university hospital of Fortaleza-CE (Jan/2016 to Jun/2017). (Continued)

\begin{tabular}{|c|c|c|c|c|}
\hline Example & Medication & Case report & Case evaluation by Risk Management & Measure taken after the investigation \\
\hline 1 & $\begin{array}{l}\text { Piperacillin + } \\
\text { Tazobactam }\end{array}$ & $\begin{array}{l}\text { After reconstitution of } \\
\text { the medication in the } \\
\text { care unit, with a } 40 \times 12 \\
\mathrm{~mm} \text { needle and water } \\
\text { for injections, the } \\
\text { presence of a foreign } \\
\text { body was observed in } \\
\text { the suspension. The } \\
\text { sample was sent to } \\
\text { Risk Management. }\end{array}$ & $\begin{array}{l}\text { - Notification to manufacturer: YES. } \\
\text { - Sample sent to manufacturer: YES. } \\
\text { - Response from the supplier: YES. After } \\
\text { analysis, the supplier concluded that the foreign } \\
\text { bodies were fragments of the butyl cap of the } \\
\text { vial. He observed that the caps were pierced } \\
\text { transversely with the wrong needle, and the } \\
\text { piercing with a 90 angle was correct using } \\
25 \times 12 \text { mm. } \\
\text { - Reimbursement by the manufacturer: NO }\end{array}$ & $\begin{array}{l}\text { - The care units were informed about the } \\
\text { correct handling of the needle and the use of } \\
\text { the } 25 \times 12 \mathrm{~mm} \text { needle was recommended in } \\
\text { the reconstitution of medications. } \\
\text { - A letter was sent to the notifier with the } \\
\text { supplier's reply. } \\
\text { - Other cases of suspected quality deviation } \\
\text { such as this were requested to continue to be } \\
\text { reported. } \\
\text { - ANVISA was not notified. }\end{array}$ \\
\hline 2 & $\begin{array}{c}\text { Lactate ringer } \\
\text { solution }\end{array}$ & $\begin{array}{l}\text { After opening the box } \\
\text { of bags in the care } \\
\text { unit, collapsing and } \\
\text { crystals were observed } \\
\text { in one of the bags. The } \\
\text { sample was sent to } \\
\text { Risk Management. }\end{array}$ & $\begin{array}{l}\text { - A technical visit was made to the Pharmaceutical } \\
\text { Supply Unit in order to verify the place where } \\
\text { the medication was stored. On this occasion, it } \\
\text { was informed that there was a recent change } \\
\text { in the place where this drug was stored and } \\
\text { that the previous temperature and storage } \\
\text { conditions were inadequate. It was concluded } \\
\text { that this is an internal problem of the institution. } \\
\text { - Notification to manufacturer: NO. }\end{array}$ & $\begin{array}{l}\text { - An active search was carried out in the units } \\
\text { and the presence of other exchanges with } \\
\text { the same quality deviation was verified. They } \\
\text { were collected immediately. } \\
\text { - The new storage location has been verified, } \\
\text { which has been presented in accordance with } \\
\text { good storage practices. } \\
\text { - A letter was sent to the notifier informing } \\
\text { about the investigative process and the } \\
\text { measures taken after the investigation. } \\
\text { - Other cases of suspected quality deviation } \\
\text { such as this were requested to continue to be } \\
\text { reported. } \\
\text { - ANVISA was not notified. }\end{array}$ \\
\hline
\end{tabular}


Table 4. Examples of drug quality deviation notifications and pharmacovigilance actions carried out in the university hospital of Fortaleza-CE (Jan/2016 to Jun/2017). (Concluded)

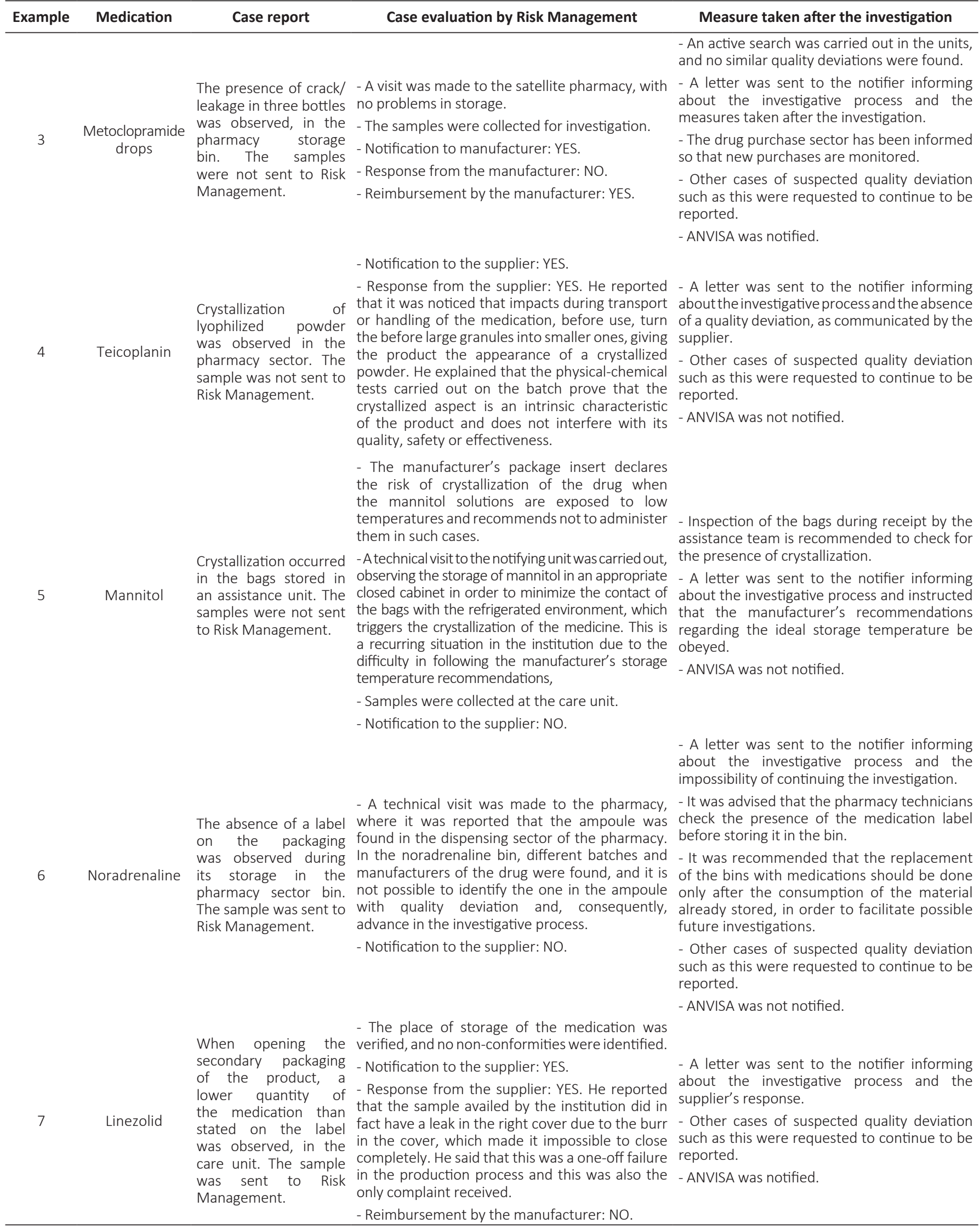




\section{Discussion}

This study analyzed the drug quality deviation notifications made by health professionals in a public university hospital that is part of the Sentinel Network of the state of Ceará. The importance of conducting post-marketing studies on the compliance, efficacy, and effectiveness of health products is increasingly evident in promoting patient safety, with sentinel hospitals being strategic locations for this surveillance to occur. ${ }^{3}$

The monthly mean of drug quality deviation notifications found in this research (3.22) was similar to the 3.75 notifications/month found in a study that evaluated quality deviations reported to the ANVISA in a teaching hospital of the Sentinel Network in Belém-PA. ${ }^{2}$ Other studies reported higher mean values: 7.54 in a sentinel university hospital in the inland of São Paulo, and 9.33 in a sentinel hospital in the private network of Porto Alegre. ${ }^{9,10}$ In contrast, a study carried out in a sentinel hospital in the Midwest described a mean number of monthly notifications of $1,72 .{ }^{12}$ The divergences observed in the studies regarding the number of monthly notifications can be explained by the possible differences between hospital profiles, the quality of the suppliers, the level of awareness of the health professionals about the importance of making notifications and the institutional culture of notification, type of notification system available, and degree of overload of the professionals..$^{14}$ In a study carried out by means of interviews at a University Hospital in Juiz de Fora on the knowledge of professionals, in the face of quality deviations, $67.3 \%$ of the interviewees stated that they did not perform the notification and that the main reason for underreporting is the lack of knowledge about where and how to notify. ${ }^{15}$

The omission of a quality deviation notification, either due to fear or to shortage of time, can delay the identification of problems and prevent the hospital management from implementing preventive measures. Thus, it is essential to sensitize health professionals to this practice..$^{3,12}$ In addition, the number of technical complaints obtained by the hospital can be considered an indicator of institutional quality, demonstrating the team's involvement with the pharmacovigilance processes and the existence of professionals concerned with the safety of patients and other members of the health service..$^{3,15}$

Another factor that may have influenced the mean number of quality deviation notifications is the combined drug distribution system adopted in the hospital, which, while guaranteeing the storage of drugs for a longer time in the pharmacy sector (a fact that limits the distribution of drugs with quality deviations) also allows for the stocking of medications and high-volume solutions in the inpatient units, which can generate problems due to inadequate storage.

In the hospital setting, the purchase of supplies is a complex process that varies according to the institution's corporate name (public or private) and involves the selection of quality products at the lowest possible cost and in order to serve the largest number of patients. In the public sector, the purchase of medications is made via a bidding process, where quality standards are previously defined. However, Nascimento et al. (2011) warn that the quality of the material is not properly specified many times, thus compromising the quality of the purchase by bidding..$^{16}$ Thus, the importance of the health professional in assessing the quality of the product is perceived before it is used, requiring notifications in this process. Quality deviation notifications help to prevent the purchase of low-quality drugs, being an important tool to justify the non-election of a supplier determiner, even if it presents the best price.

The quality deviation notifications in this study were carried out by several sectors of the hospital, demonstrating the involvement of the professionals and a culture of notification in the institution, especially by nurses and pharmacists. The pharmacy sector and the medical clinic wards were the places most involved in this process. The pharmacy is directly involved with the logistics of the drug, which facilitates the identification of deviations, as shown in other studies. ${ }^{9,10,15}$ In addition, the medical clinic wards are the inpatient units with the largest number of beds in the institution. In this setting, the nurse is the professional responsible for direct assistance to the patient and for the control of the consumable material. ${ }^{2,3,12,15}$

In this study, blood substitutes and perfusion solutions were the groups most involved with quality deviations, followed by antibacterial agents for systemic use and by immunoglobulins. Different results were found in another teaching hospital of the Sentinel Network in Belém, ${ }^{2}$ which signaled a higher prevalence of antimicrobials in relation to antihypertensive drugs, nonsteroidal anti-inflammatory drugs, and simple electrolytes, as causes of quality deviations. Differences in medication profiles can be attributed to different suppliers and to the specialty of each hospital. ${ }^{9,14}$ Such findings reflect the need for local studies to better understand this issue in hospital management.

The predominance of quality deviations in injectable formulations corroborates a previous study by Visacri and collaborators (2015) in a teaching hospital in São Paulo. ${ }^{7}$ Such formulations are frequently used in the hospital setting and can have serious health consequences if used with quality deviations. Regarding the type of quality deviation observed, all deviations in the present study

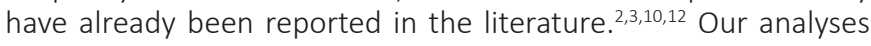
showed a higher frequency of presence of foreign body/material in suspension and occurrence of crack/bubble/leak, which was also reported in high frequency by two previous studies.,12,14 The comparison of the nature of quality deviations in the literature is hindered the lack of standardization in the classification of types of quality deviations. Gil et al. (2015) emphasize that such standardization is fundamental to the success of a system for reporting and comparing studies. ${ }^{3}$

A critical assessment of a quality deviation notification is essential, as the deviation can be confused with a normal product characteristic. The presence of foreign particles can be due to possible contamination during the preparation, originating from the environment itself or as a consequence of storage in inadequate conditions. ${ }^{15}$

The sending of the sample with quality deviation to risk management occurred for most notifications (77.55\%). The sample is essential to prove the observed quality deviation, to make it possible for the supplier to reimburse the value or to show internal problems in the institution. The financial loss shown in this study was low in relation to the total amount allocated to the purchase of medications. However, since the study site is a public hospital, which acquires low-cost generic drugs via auctions, a loss of more than 800.00 reais can cause periods of shortage.

Communication with the supplier occurred most of the time $(65.31 \%)$; however, the acknowledgment of the quality deviation (24\%) and the reimbursement of the value (25\%) were less frequent. Caon et al. (2012) reported a higher incidence of notification to the industry (87.38\%) and higher reimbursement 
(62\%), but lower acknowledgment of notifications (approximately $5 \%)$ in a private hospital in Porto Alegre. ${ }^{10}$ Factors that can justify these differences include the type and quality of the notifications made and the supplier's level of commitment to the institution. According to the Brazilian legislation, there are no specific recommendations on how the replacement of products with quality deviation by the industry should be carried out, and the problem must be solved in accordance with the rules and decisions established by the industry itself. ${ }^{10,18}$

Regarding notification to the ANVISA (20.41\%), the low frequency can be explained by the non-sending of the sample with quality deviation to the risk management area and by the identification of inadequate medication handling by the health professional or of inadequacies in the storage conditions. Although most of the notifications were included in the study, it was noticed that the filling out of the notification forms was minimal, and the investigative process carried out by risk management was the basis for the conclusion of the cases. The need is perceived to include a Continuing Education Program in the institution, in order to educate the health professionals on pharmacovigilance and its processes, and to obtain notifications with more precision and quality.

The limitations of this study include the fact that it is a single-center cross-sectional study, in which only prevalence, not incidence, can be measured, which limits the information produced; the short period of analysis (18 months); and the possibility of underreporting cases of quality deviations. In addition, the scarcity of bibliography on the subject ${ }^{19}$ and the lack of standardization in the classification of quality deviations limited the analysis and discussion of the results.

\section{Conclusion}

The present study evaluated the voluntary notifications of technical complaints of medications in a university hospital of Fortaleza - Ceará, as well as it identified the presence of a culture of notification in the study institution and opportunities for improvements in the Pharmacovigilance service. The importance of carrying out drug quality deviation notifications is evident since they can guarantee better health products on the market and more safety for patients and health professionals, in addition to generating a quality indicator for the institution. More effective institutional practices and policies related to the pharmacovigilance service should be implemented in order to increase the number and quality of spontaneous reports. In addition, an institutional education program related to pharmacovigilance activities, their importance, and their functioning in the institution can be very useful to ensure more detailed knowledge of the quality deviations of the drugs in use.

\section{Funding sources}

The research did not receive financing for its realization.

\section{Collaborators}

EFC, JAG, AIM: participated in the conception of the project. EFC: data analysis and interpretation. EFC, JAG, AIM: writing of the article and responsibility for all the information presented in the paper, ensuring accuracy and integrity of any of its parts. BCM, AFT: relevant critical review of the intellectual content and final approval of the version to be published.

\section{Acknowledgments}

We would like to thank all the pharmaceutical professionals and pharmacy technicians who collaborated to carry out this study, as well as the notifying professionals of the institution under study.

\section{Conflict of interests statement}

The authors declare that there are no conflicts of interest regarding this article.

\section{References}

1. Duarte ML, Batista LM, Albuquerque PMS. Notificações de farmacovigilância em um hospital oncológico sentinela da Paraíba. Rev Bras Farm Hosp Serv Saúde. 2014; 5(1):7-11.

2. Azulino ACO, Costa MHA, Carvalho MN et al. Queixas técnicas realizadas pelos profissionais da saúde, relacionadas aos produtos utilizados em Hospital sentinela de Belém - Pará. Rev Bras Farm Hosp Serv Saúde. 2013; 4(3):13-16.

3. Gil RB, Chaves LDP, Laus AM. Gerenciamento de recursos materiais com enfoque na queixa técnica. Rev Eletr Enf. 2015; 17(1):100-7.

4. Brasil. Ministério da Saúde. Documento de referência para o Programa Nacional de Segurança do Paciente / Ministério da Saúde; Fundação Oswaldo Cruz; Agência Nacional de Vigilância Sanitária. - Brasília : Ministério da Saúde, 2014.

5. Magalhães VP, Martins BCC, Cavalcante RMA et al. Avaliação das notificações de reações adversas a medicamentos em pacientes transplantados em um hospital sentinela de Fortaleza-Ceará. Rev Bras Farm Hosp Serv Saúde. 2017; 8(1):22-28.

6. Varallo FR, Forgerini M, Herdeiro MT, et al. Harmonization of Pharmacovigilance Regulation in Brazil: Opportunities to Improve Risk Communication. Clinical Therapeutics. 2019; 41(3):598-602.

7. Visacri MB, Souza CM, Sato CMS et al. Adverse Drug Reactions and quality deviations monitored by spontaneous reports. Saudi Pharmaceutical Journal. 2015; 23: 130-137.

8. Ministério da Saúde. Agência Nacional de Vigilância Sanitária (ANVISA). Resolução - RDC no 17, de 16 de abril de 2010. Available in: <http://bvsms.saude.gov.br/bvs/saudelegis/anvisa/2010/res0017_16_04_2010.html> Accessed on: March 30, 2018.

9. Lima PF, Cavassini ACM, Silva FAT et al. Queixas técnicas e eventos adversos a medicamentos notificados em um hospital sentinela do interior de São Paulo, 2009-2010. Epidemiol Serv Saúde. 2013; 22(4):679-686.

10. Caon S, Feiden IR, Santos MA. Desvios de qualidade de medicamentos em ambiente hospitalar: identificação e avaliação das ocorrências. Rev. Bras. Farm Hosp Serv Saúde. 2012; 3(1):23-26. 
11. Primo LP, Capucho HC. Intervenções educativas para estímulo a notificações voluntárias em um hospital de ensino da rede sentinela. Rev Bras Farm Hosp Serv Saúde. 2011; 2(2):26-30.

12. Bezerra ALQ, Silva AEBC, Branquinho NCSS et al. Análise de queixas técnicas e eventos adversos notificados em um hospital sentinela. Rev Enferm UERJ. 2009; 17(4):467-72.

13. Ferreira-Da-Silva AL, Ribeiro RA, Santos VCC, et al. Diretriz para análises de impacto orçamentário de tecnologias em saúde no Brasil. Cad Saúde Pública, 2012; 28(7):1223-38.

14. Trindade E, Vicente MG, Santanna PC et al. Modos de falhas de artigos médicohospitalares: análise das queixas técnicas envolvendo equipos de infusão notificadas à ANVISA em 2007 e 2008. BIT: Boletim Informativo de Tecnovigilância, 2010. Available in:<http://www.anvisa.gov.br/boletim_tecno/ boletim_tecno_dez_2010/boletim_tecno.html> Accessed on: 19 feb 2018.

15. Silva PL; Cornélio RAC; Araújo ALA. Farmacovigilância: conhecimento e ação dos profissionais frente a desvios de qualidade de medicamentos. Rev Bras Farm Hosp Serv Saúde. 2014; 5(1):33-37.

16. Nascimento GF, Gomes EDBF, Becalli AM et al. A Qualidade dos Produtos

17. Adquiridos por Pregão Eletrônico e a Sua Relação com a Sala de Aula no Ccaufes. VIII SEGeT - Simpósio de Excelência em Gestão e Tecnologia. 2011. Available in:< https://www.aedb. br/seget/arquivos/artigos11/30614725.pdf> Accessed on: 13 nov 2017.

18. Ministério da Saúde. Agência Nacional de Vigilância Sanitária (ANVISA). Resolução - RDC № 186, de 27 de julho de 2004. Available in:< http://www.suvisa.rn.gov.br/contentproducao/aplicacao/sesap_suvisa/arquivos/gerados/resol_ rdc186 2004.pdf> Accessed on: 25 abr. 2018.

19. Ebserh- Empresa Brasileira de Serviços Hospitalares. Sistema de Informações Gerenciais. Manual do Usuário. 2016. Available in: < http://www2.ebserh.gov.br/web/sig/vigihosp/manual-do-usuario>. Accessed on: 21 abr. 2019.

20. Oliveira AM, Rodrigues VAV, Passerini JP, et al. Queixas técnicas e reações adversas a medicamentos notificadas em um hospital regional no Brasil: um estudo transversal. ABCS Health Sci. 2018; 43(1):25-29. 